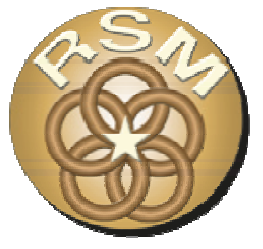

\title{
Identification of Alternatives to Reduce Shoaling and for Beneficial Use at the Bolivar Flare of the Gulf Intracoastal Waterway
}

\author{
by Paul Hamilton, Ashton Burgin, Seth Jones, \\ Lihwa Lin, and Jantzen Miller
}

PURPOSE: This U.S. Army Corps of Engineers (USACE) Regional Sediment Management (RSM) project focused on exploring innovative solutions to shoaling and sediment management issues in the Gulf Intracoastal Waterway (GIWW), specifically at the Bolivar Flare, Texas (Figure 1). The GIWW Bolivar Flare is a shoaling hotspot that requires annual maintenance dredging. The objectives of this RSM study were twofold: (1) to identify potential measures that will reduce maintenance costs and (2) to identify potential beneficial use (BU) options in the area.

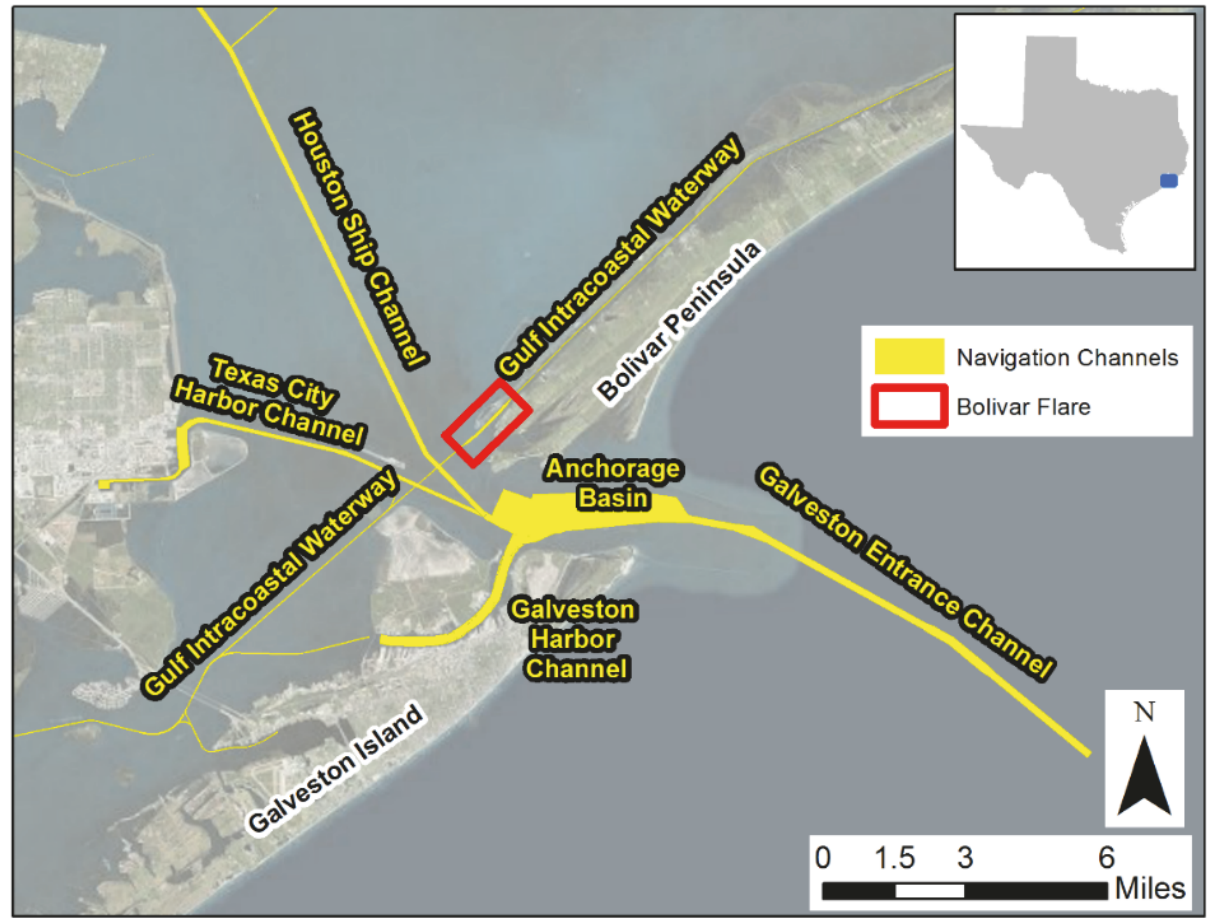

Figure 1. Regional context for the Bolivar Flare, Texas, study area.

STUDY AREA: The GIWW is a protected shallow-draft navigation channel that spans approximately 1,300 miles along the Gulf Coast of the United States, 423 miles of which traverse the Texas coast. The GIWW section of interest in this study was originally authorized in 1925 and currently serves as an important commerce corridor near the intersection of the Houston Ship Channel (HSC), the Texas City Harbor Channel (TCHC), and the Galveston Harbor Channel. 
The study area is the Bolivar Flare portion of the GIWW at the west end of Bolivar Peninsula, shown in Figure 1 (red box). The Bolivar Flare is the reach between station $314+000$ and $322+000$ (Figure 2). The GIWW is typically a 125 foot (ft)-wide navigation channel, although it widens to $500 \mathrm{ft}$ in the flare region. The authorized project depth in this reach is $13 \mathrm{ft}$ relative to mean lower low water (MLLW). The channel is typically dredged with $2 \mathrm{ft}$ additional advanced maintenance and $2 \mathrm{ft}$ of allowable over-depth. There are three dredged material placement areas (PA) in the vicinity of the flare section: PA41, PA42, and PA43.

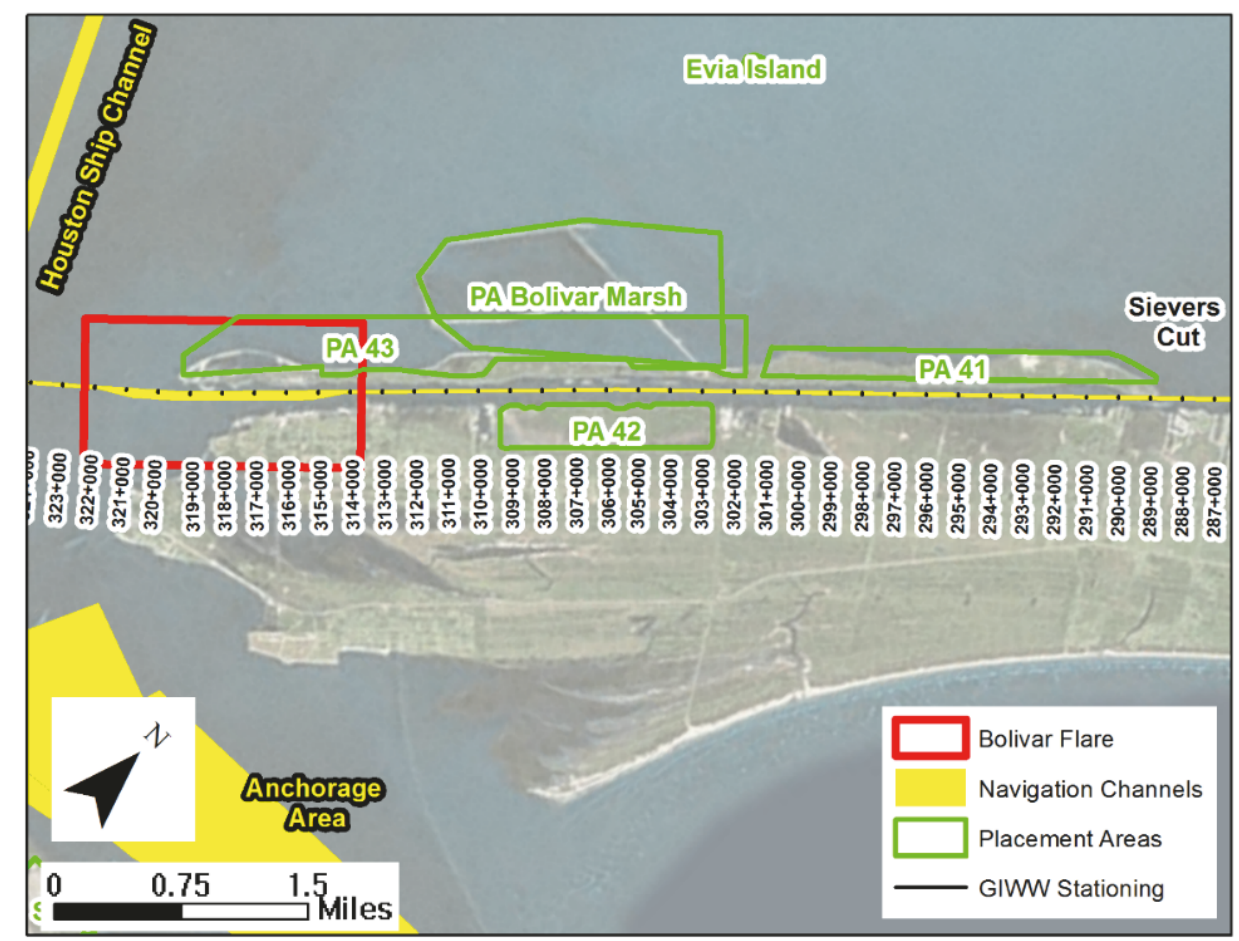

Figure 2. GIWW stationing and placement areas in the vicinity of the study area.

\section{BACKGROUND}

Historical Data. Figure 3 shows historical aerials for the study area. Figure 3A, from 1996, shows the original PA43 containment structure. It is unclear when exactly the structure was constructed. However, historical aerials back to 1969 show it in place. A separate structure is shown in Figures 3C and 3D (2010 and 2015, respectively) that was constructed in 2005 and extended in 2011 for further confinement of PA 43.

Historical Dredging Data. The Bolivar Flare is dredged on an annual basis with approximately 280,000 cubic yards (CY) of material removed each cycle. The volumetric dredging history for 2010-2016 is presented in Table 1, with the associated placement history in Table 2. Material from the Bolivar Flare, and more broadly the GIWW west of Sievers Cut, is placed in one of three placement areas. PA 41, the most easterly, is partially confined; PA 42 is upland confined; and PA 43, the most westerly, is partially confined. PA 42 and PA 43 are more frequently used than PA 41 for Bolivar Flare material. 

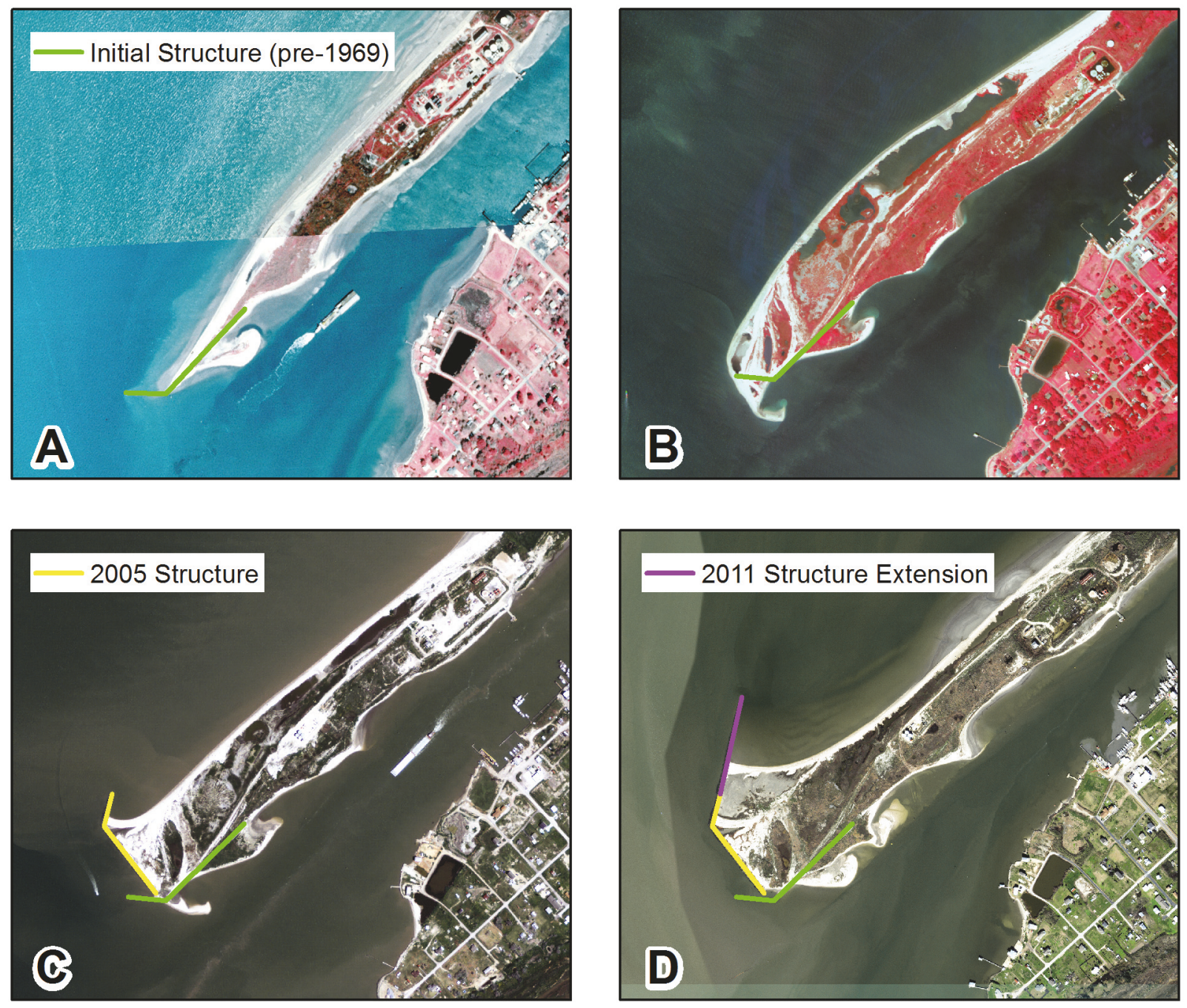

Figure 3. Historical aerials of the study area: (A) 1996, (B) 2004, (C) 2010, and (D) 2015.

One particular issue noted with respect to PA 43 is that although approximately 47,000 CY of dredged material is placed there annually (approximately 110,000 CY per year (yr) over the last $3 \mathrm{yr}$, there is little noticeable change in the shoreline of the PA over time. Material placed in PA43 appears to be potentially problematic in that repeated aerials of the region show that dredged material does not appear to remain in the PA (Figure 4). This analysis is limited to the subaerial extent of the PA, although that should not be overly simplistic in determining placed material retention. The complicating factor is that it is difficult to be certain about the fate of the placed material (i.e., whether or not it is redeposited in the Bolivar Flare.)

Another important aspect of the dredging history is the capacity and longevity of the upland confined PA42. The heavy usage in recent history (Table 2) could lead to early filling of this particular placement area. This underscores the importance in considering alternative placement strategies (e.g., beneficial use [BU] opportunities.) 
Table 1. Dredging history in the vicinity of the study area 2010-2016.

\begin{tabular}{|c|c|c|c|}
\hline $\begin{array}{c}\text { Start } \\
\text { Station }\end{array}$ & $\begin{array}{c}\text { End } \\
\text { Station }\end{array}$ & $\begin{array}{c}\text { Cumulative } \\
\text { Dredged }\end{array}$ & $\begin{array}{l}\text { Average Annual } \\
\text { Dredging } \\
{[\mathrm{CY} / \mathrm{yr}]}\end{array}$ \\
\hline $284+000$ & $287+000$ & 13,997 & 2,000 \\
\hline $287+000$ & $289+150$ & 2,288 & 327 \\
\hline $289+150$ & $302+000$ & $14,488^{1}$ & $2,070^{1}$ \\
\hline $302+000$ & $309+000$ & 174,638 & 24,948 \\
\hline $309+000$ & $315+000$ & 27,775 & 3,968 \\
\hline $315+000$ & $320+000$ & $1,355,790$ & 193,684 \\
\hline $320+000$ & $321+000$ & 610,706 & 87,244 \\
\hline $321+000$ & $328+500$ & $53,753^{1}$ & $7,679^{1}$ \\
\hline $328+500$ & $332+500$ & 114,214 & 16,316 \\
\hline $332+500$ & $340+000$ & 125,238 & 17,891 \\
\hline \multicolumn{4}{|c|}{$\begin{array}{l}\text { Notes: } \\
\text { 1. There were no dredging contracts found for these reaches in } \\
\text { the period 2010-2016; volumes for these reaches were } \\
\text { calculated using 1990-2016 }\end{array}$} \\
\hline
\end{tabular}

Table 2. Dredged material placement history in the vicinity of the study area 2010-2016.

\begin{tabular}{|ccccc|}
\hline $\begin{array}{c}\text { Placement } \\
\text { Area }\end{array}$ & Type & $\begin{array}{c}\text { Cumulative } \\
\text { Placement } \\
{[\mathrm{CY}]}\end{array}$ & $\begin{array}{c}\text { Average Annual } \\
\text { Placement } \\
{[\mathrm{CY} / \mathrm{yr}]}\end{array}$ & Years Used \\
\hline 41 & Semi-Confined & 203,023 & 29,003 & 2010,2014 \\
42 & Upland-Confined & $1,638,912$ & 234,130 & $2010,2012,2013,2014,2015,2016$ \\
43 & Semi-Confined & 326,974 & 46,711 & $2014,2015,2016$ \\
\hline
\end{tabular}




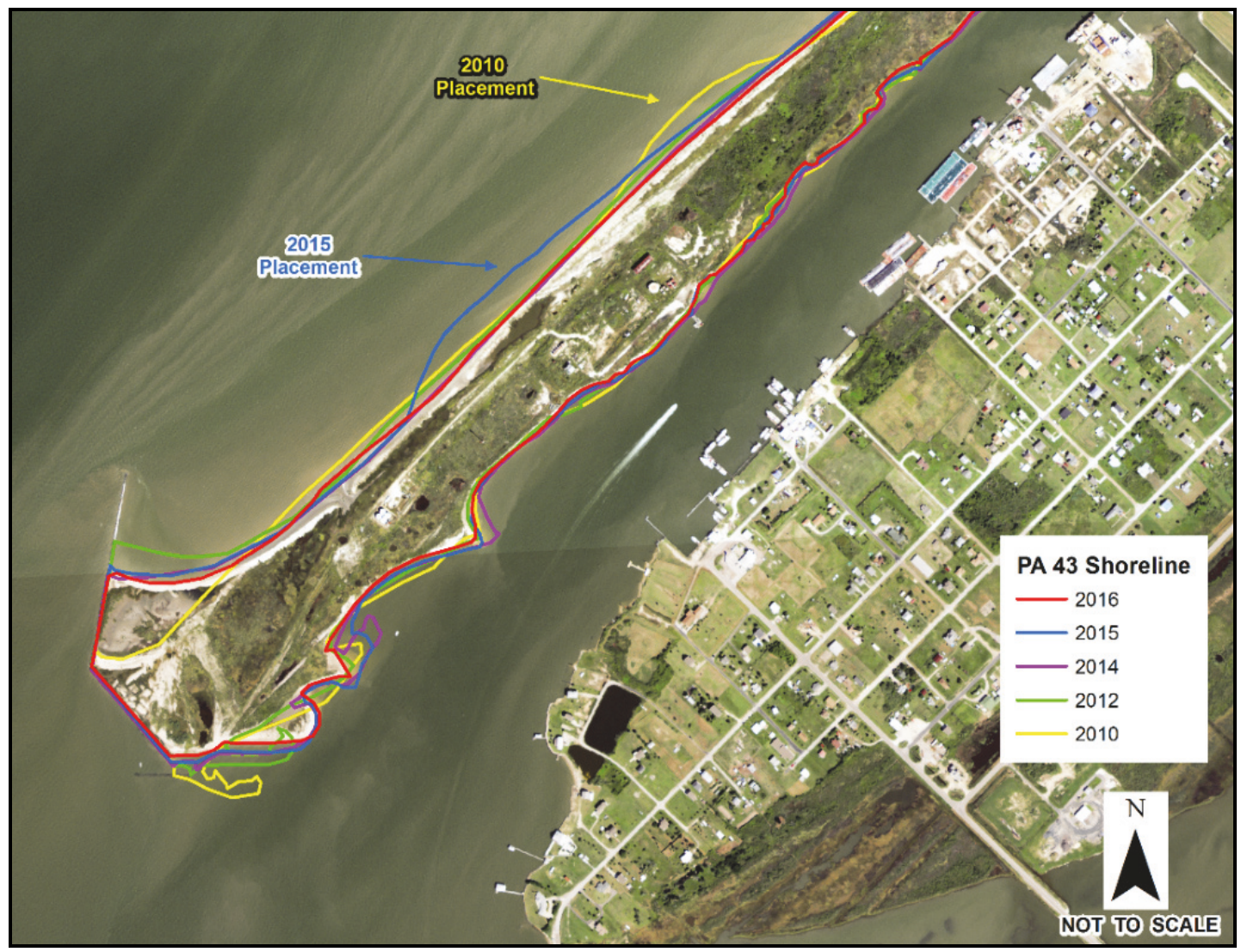

Figure 4. Historical shoreline positions of the peninsula containing PA43 from 2010 to 2016.

Datum Information. Table 3 shows the water-level datum information near the project area at the National Oceanic and Atmospheric Administration (NOAA) Station 8771450 at Galveston Pier 21, including the relationship to the North American Vertical Datum of 1988.

\begin{tabular}{|c|c|c|}
\hline Datum & Description & $\begin{array}{c}\text { Value } \\
\text { [ft] }\end{array}$ \\
\hline MHHW & Mean Higher-High Water & 5.79 \\
\hline MHW & Mean High Water & 5.70 \\
\hline MSL & Mean Sea Level & 5.21 \\
\hline MTL & Mean Tide Level & 5.20 \\
\hline MLW & Mean Low Water & 4.68 \\
\hline MLLW & Mean Lower-Low Water & 4.38 \\
\hline NAVD88 & North American Vertical Datum of 1988 & 4.52 \\
\hline
\end{tabular}

Grain Size Data. Figure 5 shows grain size data obtained from the USACE Galveston District sediment sampling records. The material through the study area is relatively sandy with a representative median grain size of 0.15 millimeter. The material in the HSC becomes progressively finer farther away from the Galveston Entrance Channel. 


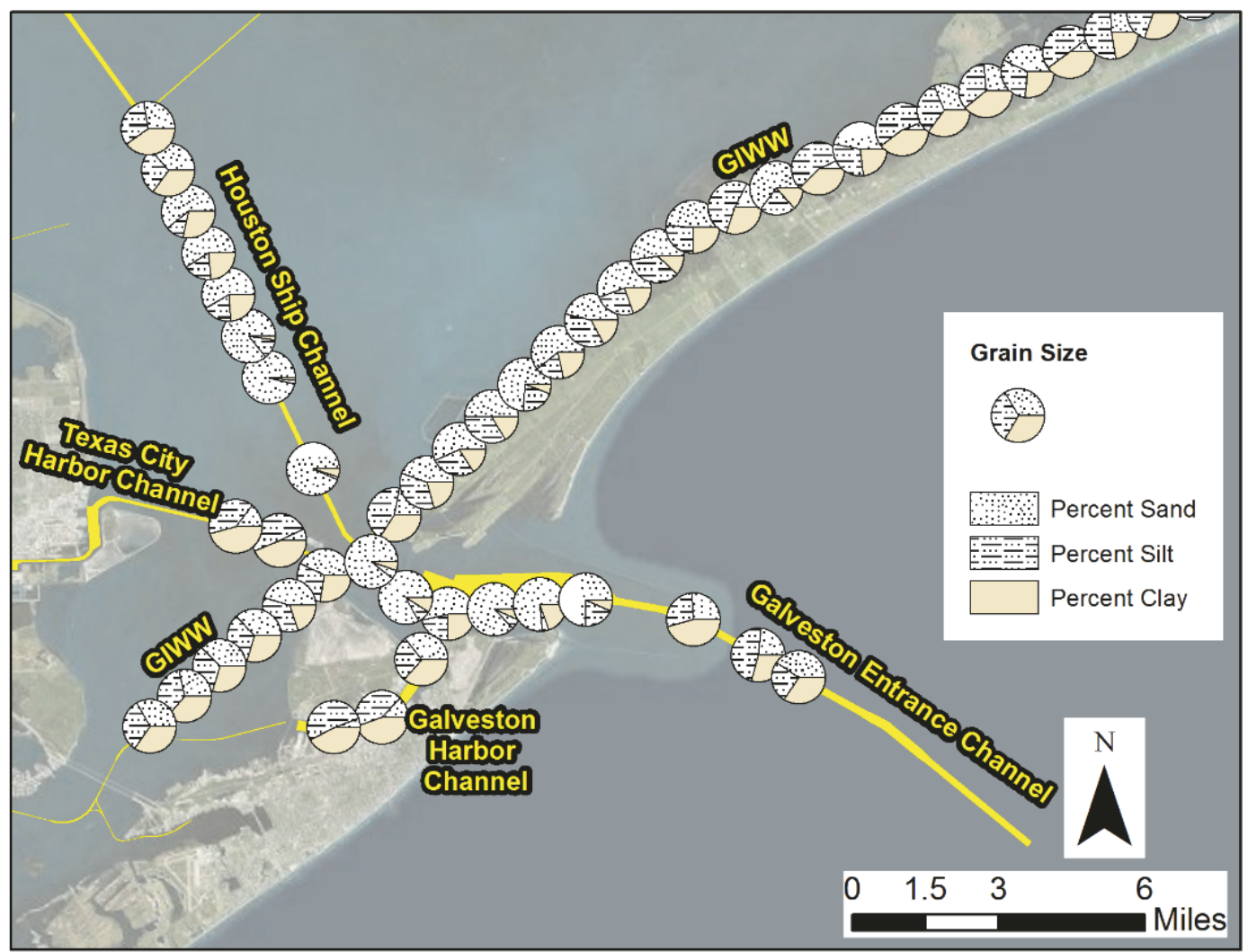

Figure 5. Grain size data in the vicinity of the study area.

\section{METHODS}

eHydro/CSAT. Hydrographic surveys on navigation channels are processed with eHydro (Littell and Gavin 2015) upon collection and housed on the USACE Navigation Portal (http://navigation.usace.army.mil). The Corps Shoaling Analysis Tool (CSAT) (Dunkin and Mitchell 2015), a calculation of shoaling rates based on repeated surveys, was run in the vicinity of the project area. Survey data from 2010 to 2015 were used in CSAT. The average shoaling rate near the study area was $1.44 \mathrm{ft} / \mathrm{yr}$ in the reach $290+000$ to $318+000$, and $2.16 \mathrm{ft} / \mathrm{yr}$ for the reach $318+000$ to $320+000$. The CSAT output was used as a second source of shoaling information, in addition to the dredging history, as well as a visual representation of the progression between surveys.

Numerical Modeling. The Coastal Modeling System (CMS) was used to simulate the physical processes in the vicinity of the project area. The CMS is a hydrodynamic and wave model that also calculates sediment transport and morphologic change (Demirbilek and Rosati 2011). Figure 6 shows the modeling domain for this study. The simulations were run for $1 \mathrm{yr}$ covering all of 2010. This is considered to be a broadly representative year to simulate, characteristic of typical environmental conditions. Wind and wave forcing was obtained from the NOAA National Data Buoy Center buoy number 42035. The sediment transport coefficients in the model were calibrated based on the modeled sediment accumulation and the historical dredging data from 2010 to 2016 (Table 1). 


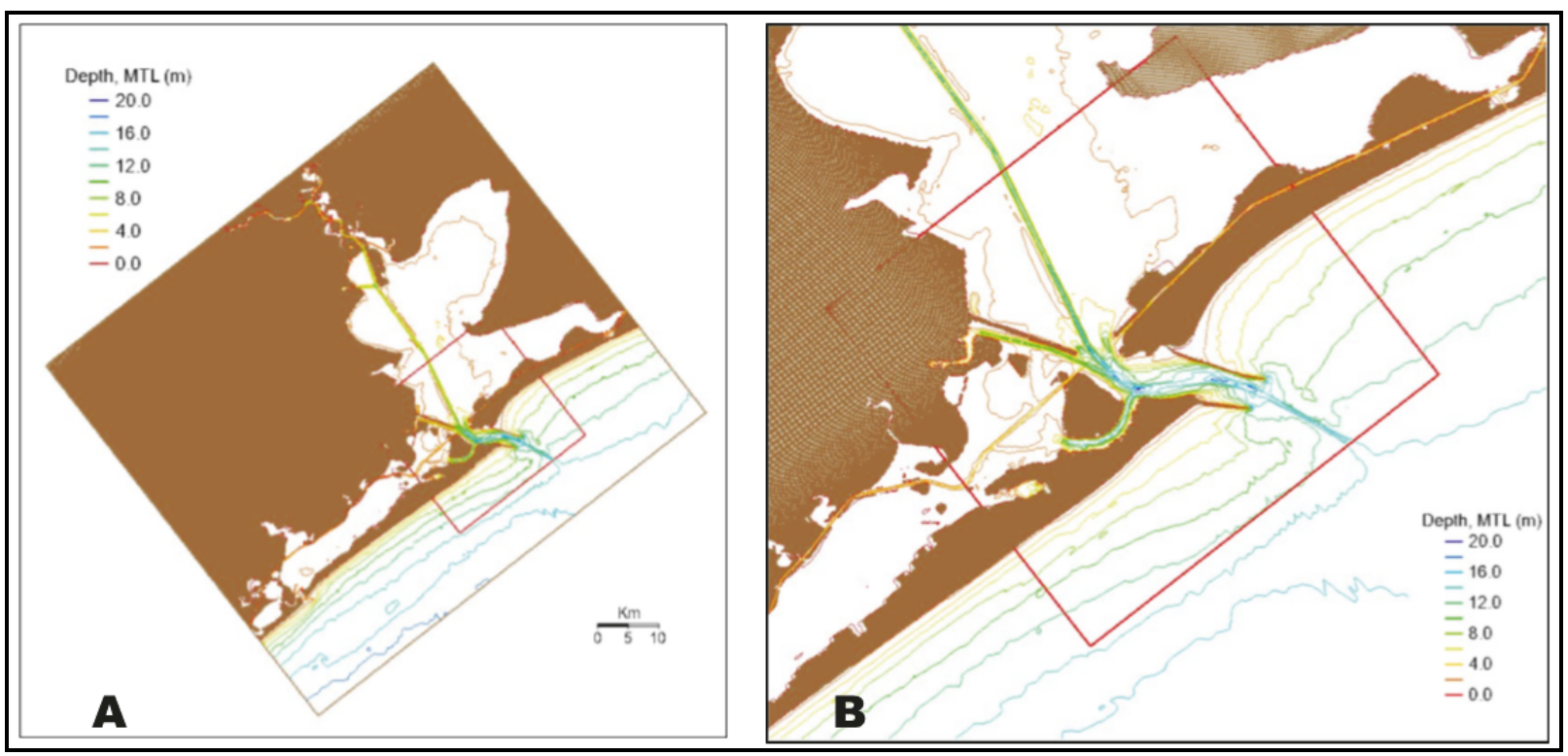

Figure 6. CMS domain for $(\mathrm{A})$ the regional and $(\mathrm{B})$ the local study area.

Sediment Budget Analysis. A sediment budget was created for the study area using available historical data and informed by the numerical model results. The data were amalgamated using the Sediment Budget Analysis System (SBAS) (Rosati and Kraus 2001 [rev. 2003]; Dopsovic et al. 2002 [rev. 2003]). Figure 7 shows the littoral cells and transport fluxes for the sediment budget in the study area.

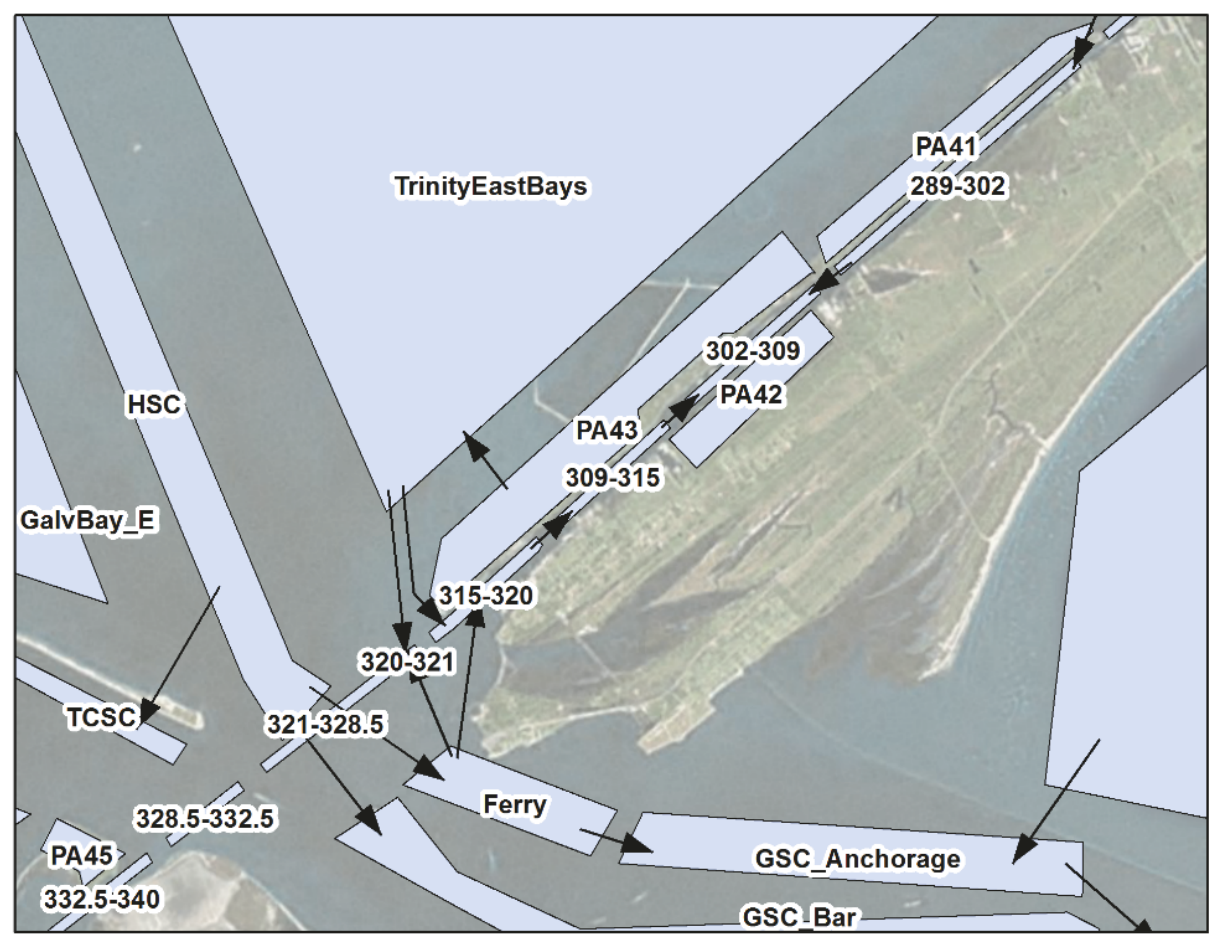

Figure 7. SBAS littoral cells and fluxes. 
EXISTING CONDITIONS: A characterization of the project area existing conditions, with particular emphasis on the sediment transport properties, was undertaken through a variety of means. The potential issue with material placed in PA43 was discussed previously. Another potential issue in the area is spit growth on the south side of the peninsula containing PA 43. Although the landform growth approaches the GIWW, this does not appear to impact navigation. Surveys show a shoaling pattern with its origin in the southwest of Bolivar Flare and progressive sedimentation to the northeast. Given this, spit propagation is likely not a governing cause of sedimentation. Prior sediment budget analyses (e.g., Frey et al. 2016; Morang 2006) concluded that regional sediment transport was ebb dominated. On the more granular scale considered here, there is sedimentation during both flood and ebb.

ALTERNATIVES ANALYSIS: Three alternatives were considered to understand how they may help alleviate shoaling issues in the study area: (1) an extension of the PA43 containment structure, (2) a sediment trap, and (3) a structural measure north of the channel (Figure 8). These alternatives were simulated with a numerical model and shoaling analyses conducted in the locations indicated in Figure 9.

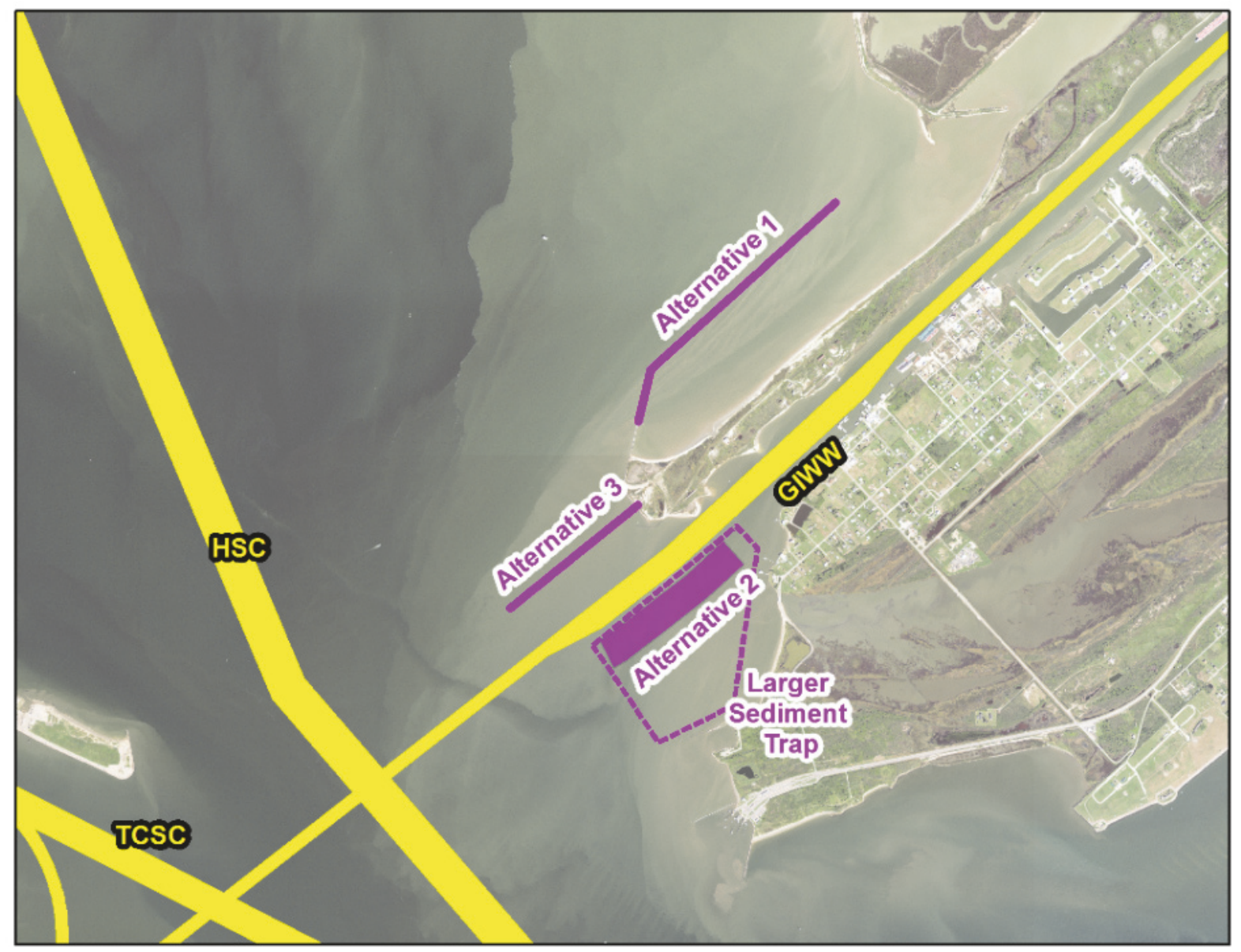

Figure 8. Shoaling reduction alternatives. 


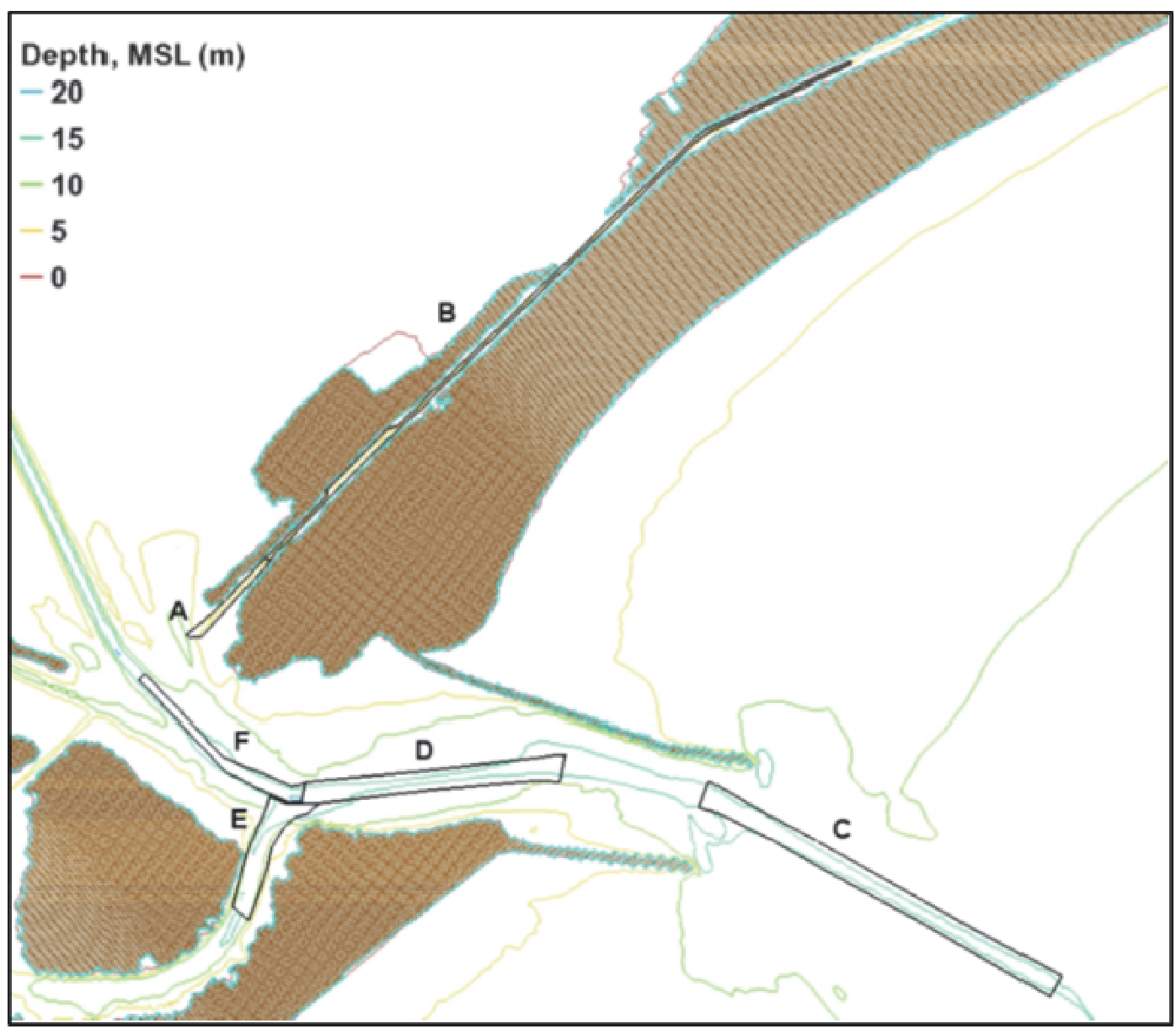

Figure 9. Shoaling analyses areas from the CMS modeling.

Alternative 1 consists of an extension of the containment structure along the boundary of PA43 to better confine placed sediment. The structure extension continues from the end of the existing structure along the boundary of PA43 to the northeast before turning to follow the boundary of PA43. The purpose of this structure is to limit the amount of material placed in PA43 that is reworked and deposited in the Bolivar Flare. Alternative 2 consists of a sediment trap dredged south of the Bolivar Flare meant to intercept sediment transported through the Bolivar Roads inlet. The sediment trap is approximately 30 acres dredged to a depth of $-12 \mathrm{ft}$ MLLW. Alternative 3, a structure built as a continuation of PA43, was considered to explore the potential benefit of interrupting sediment transport from Galveston Bay. These alternatives are compared to Alternative 0 (i.e., no action), which consists of no physical changes to the study area and thereby no change in dredging cycle.

Figure 10 shows the morphological evolution through each simulation, with a summary of the associated shoaling compiled in Table 4. 


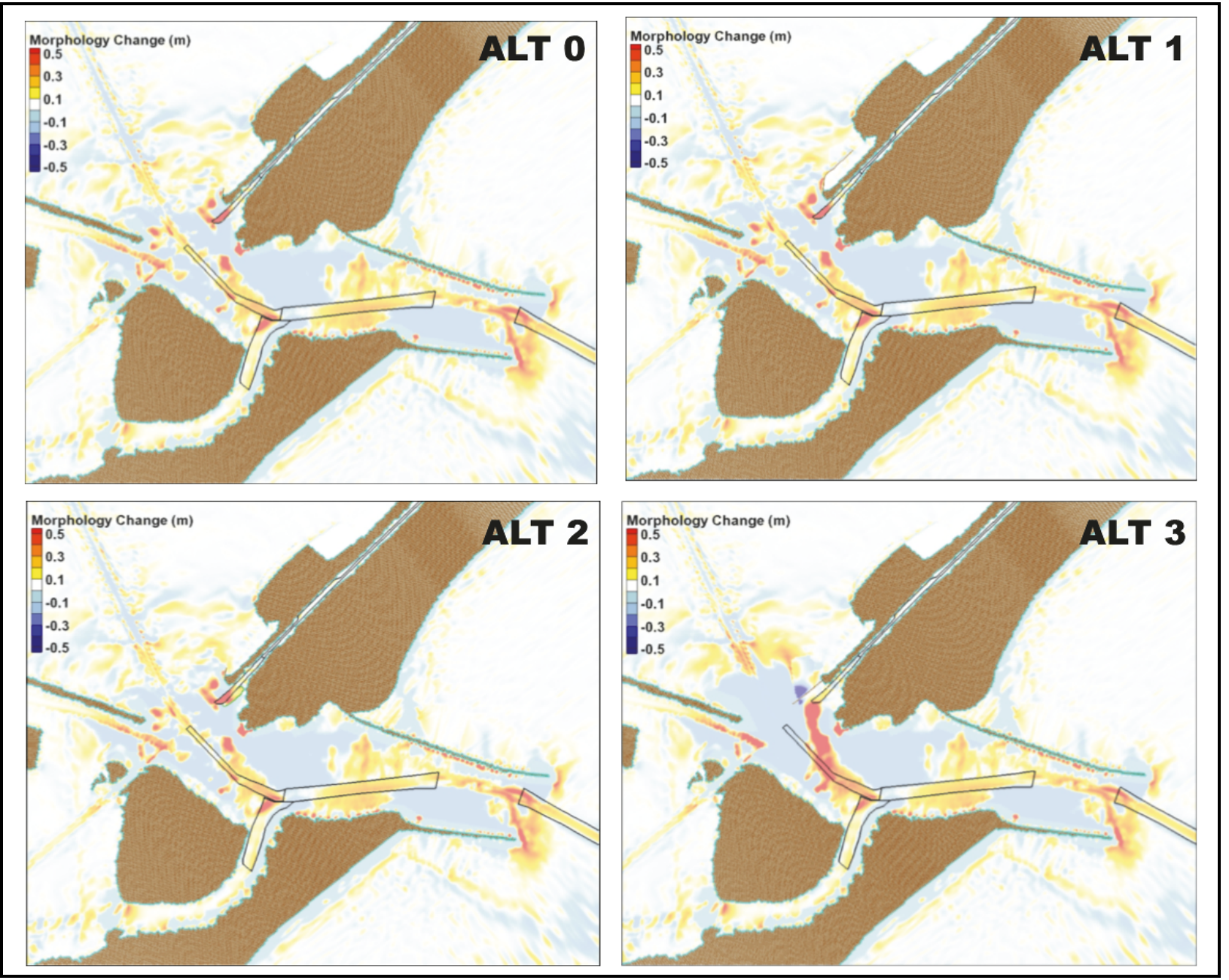

Figure 10. Morphological change simulated from the CMS modeling.

Table 4. Total sediment accumulation (cubic yards) from the CMS modeling of existing condition (AO) and alternatives.

\begin{tabular}{|c|c|c|c|c|c|}
\hline Area ID & $\begin{array}{c}\text { Area } \\
\text { Description }\end{array}$ & Alt 0 & Alt 1 & Alt 2 & Alt 3 \\
\hline$A$ & Bolivar Flare & 141,780 & 135,840 & 127,258 & 22,140 \\
\hline B & E GIWW & 15,560 & 15,690 & 15,424 & 540 \\
\hline C & Outer Channel & 800,840 & 800,120 & 800,770 & 645,500 \\
\hline D & $\begin{array}{l}\text { Inner Bar } \\
\text { Channel }\end{array}$ & 286,930 & 286,390 & 286,760 & 214,260 \\
\hline$E$ & $\begin{array}{l}\text { Bolivar Rd to } \\
\text { Exxon Dock }\end{array}$ & 152,050 & 151,480 & 151,890 & 90,255 \\
\hline $\mathrm{F}$ & $\mathrm{HSC}$ & 210,500 & 211,090 & 210,130 & 291,400 \\
\hline
\end{tabular}


The modeled alternatives were effective at reducing shoaling at the Bolivar Flare, however to a very limited extent. This is particularly true of Alternative 1. The ultimate fate of material placed in PA43 is unknown. It does not stay in the placement area, but given these results, it also appears that it is not reworked into the Bolivar Flare, or at the very least, more confinement of the PA was not helpful.

Alternative 2 was more effective in reducing sediment accumulation in the Bolivar Flare. However, a $10 \%$ reduction is not sufficient to extend the dredging cycle to $2 \mathrm{yr}$ rather than the current annual cycle. Furthermore, the sediment trap itself would require annual maintenance. The proximity to the tidal inlet at Bolivar Roads leads to a high sediment flux at both ebb and flood, and the nearby depressions are efficient sediment sinks.

Alternative 3, although it would substantially reduce shoaling in the Bolivar Flare, is not a viable option given the substantial impacts to the HSC. Furthermore, a structure in that area would impact vessel traffic turning north to the HSC from the GIWW (Figure 11). There are also constructability and cost issues with this plan; the proposed alignment quickly ventures into deeper water.

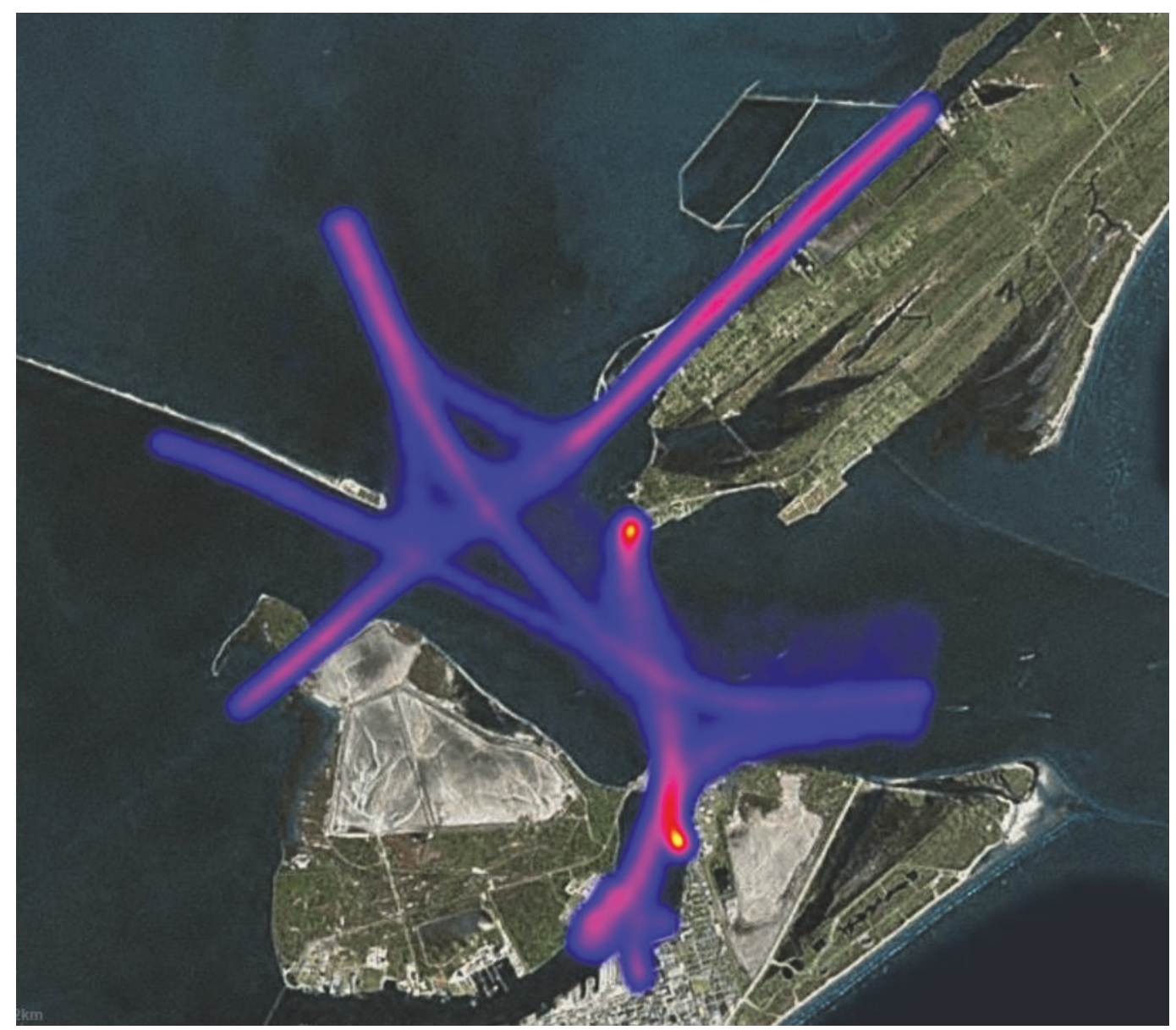

Figure 11. Automatic Identification System Analysis Package (AISAP) vessel-track heat map for 2015. (AISAP 2015). 
Given the modeling results of the potential alternatives, none were favorable for implementation due to either low benefits or high cost. A present-value benefit-cost ratio was not calculated for these alternatives; the costs clearly outweigh the benefits. Townsend et al. (2015) identified possible alternatives to reduce shoaling in the HSC. These concepts could be revisited as a means of reducing the regional dredging requirements; however, it is difficult to estimate the impact these would have specifically on the Bolivar Flare.

Understanding that Bolivar Flare is a difficult area to reduce shoaling, BU options for sediment placement were also considered. This provides an opportunity to maximize wise regional sediment management decisions while preserving capacity in the upland confined PA42 and extend its life.

Table 5 lists various BU options and the associated advantages and disadvantages; the locations are shown in Figure 12. Identified is the pump distance for each of the alternatives, a few comments, and a qualitative assessment of potential for BU. The potential for BU is based on feasibility from a pump distance perspective, relative ease in finding a non-federal sponsor, and any other additional factors. This list is not exhaustive but indicative of the local options.

Table 5. Potential BU alternatives.

\begin{tabular}{|c|c|c|c|}
\hline BU Site & $\begin{array}{l}\text { Pump Distance } \\
\text { [mi.] }\end{array}$ & $\begin{array}{l}\text { Potential } \\
\text { for BU }\end{array}$ & Notes \\
\hline \multicolumn{4}{|c|}{ Beach Nourishment } \\
\hline Bolivar Beach & $5-6$ & High & $\begin{array}{l}\text { Sediment starved location that is a good } \\
\text { candidate for BU. TGLO would likely be } \\
\text { interested. }\end{array}$ \\
\hline Galveston Beach & $\begin{array}{l}8 \text { (East Beach) } \\
>8 \text { (Further } \\
\text { West along } \\
\text { the Island) }\end{array}$ & High & $\begin{array}{l}\text { Active interest in nourishing Galveston beaches } \\
\text { from Galveston Island Park Board. }\end{array}$ \\
\hline Texas City Dike & $2-3$ & Medium & $\begin{array}{l}\text { There are two PAs for beach placement on the } \\
\text { northeast side; these are typically used by the } \\
\text { TCSC if at all }\end{array}$ \\
\hline Bolivar Pocket Beach & 4 & Medium & $\begin{array}{l}\text { Short pump distance; this is not an active BU } \\
\text { site, so would require coordination }\end{array}$ \\
\hline \multicolumn{4}{|c|}{ Island Creation / Habitat Creation } \\
\hline Evia Island & 5 & Medium & $\begin{array}{l}\text { Originally part of HSC as a BU site. Appears to } \\
\text { have capacity for placement, though a very } \\
\text { limited capacity. }\end{array}$ \\
\hline Goat Island & 12 & Low & $\begin{array}{l}\text { Long pump distance to a location that is not a } \\
\text { current BU project }\end{array}$ \\
\hline \multicolumn{4}{|c|}{ Marsh / Wetland Placement } \\
\hline Bolivar Marsh & $2-3$ & Medium & $\begin{array}{l}\text { Site is potentially "completed." Would require } \\
\text { construction at the PA boundary, and EA, and } \\
\text { considerable coordination with the Beneficial } \\
\text { Users Group. }\end{array}$ \\
\hline $\begin{array}{l}\text { Goat Island / Pepper } \\
\text { Grove Cove }\end{array}$ & $13-14$ & Low & $\begin{array}{l}\text { Long pump distance to a location that is not a } \\
\text { current BU project }\end{array}$ \\
\hline
\end{tabular}


Beach nourishment alternatives include the Bolivar Beach, Galveston Beach, beaches on the Texas City Dike, and the Bolivar Pocket Beach. The Texas General Land Office is a potential non-federal sponsor for any of these options. Furthermore, the Galveston Park Board is a potential non-federal sponsor; they are very active with respect to beach nourishment along Galveston Island. These four beach locations have relatively good BU prospects due to general interest in beach nourishment and manageable pump distances. Other options include island creation or marsh placement. Evia Island is nearby (Figure 12) but has minimal capacity available according to aerial imagery. Goat Island is identified, but the pump distance is prohibitively long. The beaches on Bolivar Peninsula or Galveston Island are likely the best alternatives. These are sediment-starved areas where there is interest in additional sediment supply. The Bolivar Pocket Beach is an eroding area that would be convenient from a pump-out distance perspective; however, a possible non-federal sponsor was not identified. This location is also relatively small in comparison to the other beach placement alternatives and may not support routine usage.

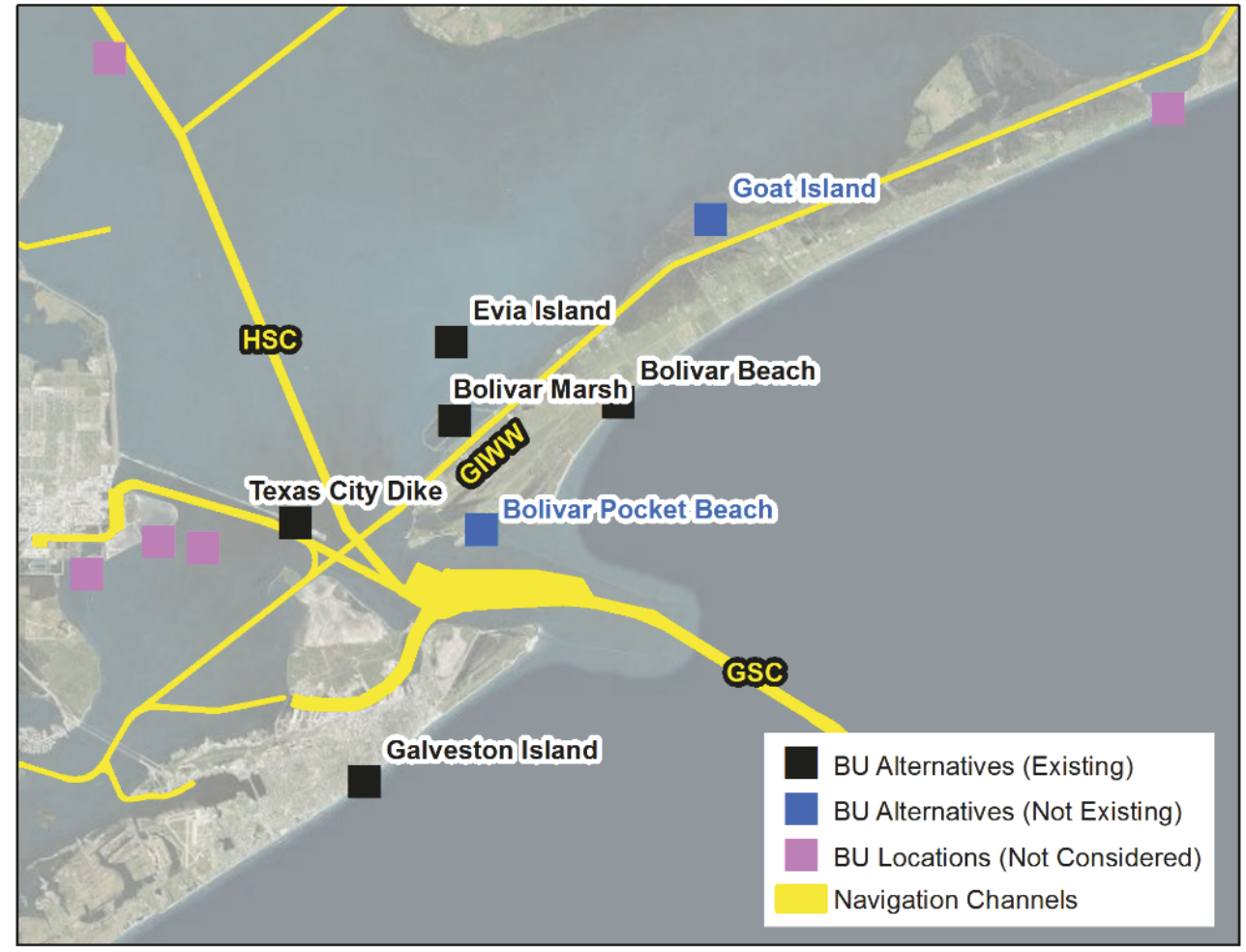

Figure 12. BU alternative locations.

Another option for BU is mining the upland confined PA42 for use at one of the identified sites. The material in PA42 is thought to be generally sandy given the adjacent sandy shoal material. This would act to increase habitat value while also providing more capacity in the PA.

One final option for sediment management in the area is a larger sediment trap south of the Bolivar Flare (Figure 8). Although the sediment trap evaluated as Alternative 2 would not be economically justified from a purely operations and maintenance perspective, a larger sediment trap could serve as a sediment source for ecosystem restoration and flood risk management projects. The trap would also provide the desired shoaling reduction in the Bolivar Flare and 
create synergy between business lines. The sandy material in the area would be well suited for one of the beach placement locations discussed previously.

SUMMARY AND CONCLUSIONS: The high shoaling rates at the Bolivar Flare are difficult to mitigate given the high regional sediment flux due to the proximity to the tidal inlet and the multiple other adjacent channels. The simulation of Alternative 3 shows how structural alternatives in the area would cause hydrodynamic changes sufficient to impact other navigation projects in the area (e.g., the Galveston Ship (Entrance) Channel [GSC], the HSC, and the TCHC). As noted, some of the options outlined by Townsend et al. (2015) could be revisited to reduce dredging requirements regionally, but it is difficult to quantify the effect for the Bolivar Flare.

Given the difficulty in identifying an alternative to reduce shoaling in the Bolivar Flare, placement alternatives were considered. There are a variety of viable BU options in the area. The beach on Bolivar Peninsula is likely the best long-term BU alternative. The future direction for this project area will be to identify and coordinate with BU partners for construction through dredging contracts.

ADDITIONAL INFORMATION: This USACE Regional Sediment Management Technical Note (RSM-TN) was prepared by Paul Hamilton, Ashton Burgin, Seth Jones, and Jantzen Miller, USACE Galveston District (SWG); and Lihwa Lin, U.S. Army Engineer Research and Development Center (ERDC), Coastal and Hydraulics Laboratory (CHL). This study was conducted as an activity of the USACE National RSM Program, a Navigation Research, Development, and Technology (RD\&T) portfolio program administered by Headquarters (HQ) USACE. Additional information pertaining to the SWG RSM investigations can be obtained from Paul Hamilton (Paul.B.Hamilton@usace.army.mil), the SWG RSM Point of Contact. For information pertaining to the National RSM Program, please consult the RSM website (http://rsm.usace.army.mil), or contact the USACE National RSM Program Manager, Linda Lillycrop (Linda.S.LillycropC@usace.army.mil). For further information pertaining to this RSMTN, please contact Paul Hamilton.

This RSM TN should be cited as follows:

Hamilton, P., A. Burgin, S. Jones, L. Lin, and J. Miller. 2019. Identification of Alternatives to Reduce Shoaling and for Beneficial Use at the Bolivar Flare of the Gulf Intracoastal Waterway. ERDC/TN RSM-19-3. Vicksburg, MS: U.S. Army Engineer Research and Development Center. http://dx.doi.org/10.21079/ $\underline{11681 / 32388}$

\section{REFERENCES}

Automatic Identification System Analysis Package (AISAP). 2015. http://ais-portal.usace.army.mil/

Demirbilek, Z., and J. Rosati. 2011. Verification and Validation of the Coastal Modeling System: Executive Summary. ERDC/CHL-TR-11-10. Vicksburg, MS: U.S. Army Engineer Research and Development Center.

Dopsovic, R., L. Hardegree, and J. D. Rosati. 2002 (rev. 2003). Sediment Budget Analysis System-A: SBAS-A for Arcview $($ Application. ERDC/CHL CHETN-XIV-7. Vicksburg, MS: U.S. Army Engineer Research and Development Center. 
Dunkin, L. M., and K. N. Mitchell. 2015. Quantitative approach to navigation channel asset management. In Proceedings, Western Dredging Association and Texas A\&M University Center for Dredging Studies, Dredging Summit and Expo 2015. 22-25 June, Houston, TX.

Frey, A., A. Morang, and D. King. 2016. Galveston Island, Texas, Sand Management Strategies. ERDC/CHL-TR16-13. Vicksburg, MS: U.S. Army Engineer Research and Development Center.

Littell, M., and W. S. Gavin. 2015. eHydro: Enterprise hydrosurvey processing within a GIS framework. In Proceedings of the U.S Hyrdo 2015 Conference, National Harbor, Maryland, USA, 16-19 May 2015.

Morang, A. 2006. North Texas Sediment Budget. ERDC/CHL-TR-06-17. Vicksburg, MS: U.S. Army Engineer Research and Development Center.

Rosati, J. D., and N. C. Kraus. 2001 (rev. 2003). Sediment Budget Analysis System (SBAS): Upgrade for Regional Applications. ERDC/CHL CHETN-XIV-3. Vicksburg, MS: U.S. Army Engineer Research and Development Center. http://acwc.sdp.sirsi.net/client/search/asset/1011242

Townsend, K., R. Thomas, T. Campbell, S. Willey, A. Frey, A. Morang, and D. King. 2015. Identification of Alternatives to Reduce Shoaling in the Galveston Entrance Channels, Texas. ERDC/CHL CHETN-XIV-45. Vicksburg, MS: U.S. Army Engineer Research and Development Center.

NOTE: The contents of this technical note are not to be used for advertising, publication, or promotional purposes. Citation of trade names does not constitute an official endorsement or approval of the use of such products. 